\begin{tabular}{c} 
Brazilian Journal \\
of Chemical \\
Engineering \\
\hline
\end{tabular}

ISSN 0104-6632

Printed in Brazil

www.abeq.org.br/bjche

Vol. 31, No. 04, pp. 1003 - 1011, October - December, 2014

dx.doi.org/10.1590/0104-6632.20140314s00002537

\title{
REMOVAL OF LACTOBIONIC ACID BY ELECTRODIALYSIS
}

\author{
J. B. Severo Júnior ${ }^{*}$, T. L. M. Alves and H. C. Ferraz \\ Programa de Engenharia Química/COPPE, Universidade Federal do Rio de Janeiro, \\ Cidade Universitária, CP 68502, 21941-972, Rio de Janeiro - RJ, Brasil. \\ Phone: (55) (21) 25628343, Fax: (55) (21) 25628300 \\ E-mail: jsevero@peq.coppe.ufrj.br
}

(Submitted: February 11, 2013; Revised: September 16, 2013 ; Accepted: December 2, 2013)

\begin{abstract}
Lactobionic acid has a number of applications, such as in cosmetic formulations and detergents, as well as in the medical field, where it is used for the preservation of organs destined for transplantation. Previous studies have reported that a promising alternative procedure for the production of lactobionic acid is the biotechnological route, using permeabilized cells of Zymomonas mobilis to produce sorbitol and lactobionic acid from fructose and lactose. However, the acid produced during the process accumulates in the reaction medium, causing enzyme deactivation. It was found that this problem can be avoided by coupling an electrodialysis unit to the reaction vessel, resulting in efficient removal of the acid from the reaction medium and improved the stability of the enzyme. These tests employed a synthetic mixture containing lactobionic acid, sorbitol, lactose, and fructose, and a factorial design was performed to identify the most influential variables. The $\mathrm{NaCl}$ concentration in the concentrate stream, together with the potential difference, exerted the greatest effects on the rate of removal of lactobionic acid. In all experiments, the removal efficiency exceeded $95 \%$. The best conditions for the system investigated were a potential of $60 \mathrm{~V}$, and $\mathrm{NaCl}$ concentrations of 3 and $25 \mathrm{~g} \mathrm{~L}^{-1}$ in the concentrate stream and the electrode compartment, respectively. Keywords: Electrodialysis; Zymomonas mobilis; Lactobionic acid; Experimental design.
\end{abstract}

\section{INTRODUCTION}

The use of lactobionic acid in cosmetic formulations is already established. Another potential application based on its biodegradability and lack of toxicity is the use in the manufacture of substances with surfactant properties, such as detergents. Nevertheless, the greatest commercial application is in the medical field, as the main constituent of fluid for organ preservation during the procedure of transplantation. Lactobionic acid is obtained industrially by dehydrogenation of the lactose using a metallic catalyst (Splechtna et al., 2001; Dhariwal et al., 2006; Paul and Patrick, 2009; Pedruzzi et al., 2011; Severo Júnior et al., 2011; Malvessi et al., 2013).
Recent studies have shown some alternatives for the production of lactobionic acid, as for example, biotechnological and electrochemical processes, both still in development (Miyamoto et al., 2000; Splechtna et al., 2001; Dhariwal et al., 2006; Severo Júnior et al., 2011; Malvessi et al., 2013). According to Jonas and Silveira (2004), a promising route for production of lactobionic acid is from lactose and fructose by enzymatic catalysis using permeabilized cells of $Z y$ momonas mobilis. The enzyme glucose fructose oxidoreductase (GFOR) produced only by the bacterium Zymomonas mobilis is capable of promoting simultaneously the oxidation of aldoses to their respective aldonic acids and the reduction of ketoses to their respective polyols (Zachariou and Scopes, 1986).

*To whom correspondence should be addressed 
Natural substrates of GFOR are fructose and glucose. However, the aldonic acid resulting from this catalysis is gluconic acid, which is a low market value product. Lactobionic acid, on the other hand, is much more valuable, rendering its production by Zymomonas mobilis very attractive (Jonas and Silveira, 2004).

Just as important as the synthesis step is the downstream processing, that can have an enormous impact on the product final price. Conventional separation techniques include precipitation, ion exchange, among others. A more recent process is electrodialysis, which employs an electrical gradient to promote the separation of ionic species. In addition to accomplishing separation without adding chemicals to the medium, electrodialysis allows the continuous separation of the ionic product, which can contribute to increased conversion and avoid enzyme inactivation by accumulation of product in the reaction medium (Furlinger et al., 1998; Ferraz et al., 2001).

Ferraz et al. (2001) evaluated the production and simultaneous separation of sorbitol and gluconic acid by an electrodialysis unit coupled to a membrane bioreactor containing permeabilized and immobilized cells of Zymomonas mobilis. The results presented by these authors showed that the electrodialysis unit coupled to the bioreactor allowed an efficient removal of gluconic acid from the reaction medium, as well as an improvement in the stability of the enzyme, without reduction of the reaction rate, even after 60 hours of reaction. In addition, several studies reported in the literature show that this process offers considerable economic potential for the recovery and production of organic acids including citric acid, fumaric acid, and galacturonic acid (Novalic et al., 2000; Choi et al., 2002; Tongwen and Weihua, 2002; Bélafi-Bakó et al., 2004; Mólnar et al., 2009; Mólnar et al., 2010).

Thus, this work aims at evaluating the removal of lactobionic acid from synthetic mixtures containing sorbitol, lactose and fructose by electrodialysis, based on factorial design, to verify the feasibility of the integration of this step with a bioreactor containing permeabilized cells of Zymomonas mobilis.

\section{MATERIALS AND METHODS}

The electrodialysis unit comprises 9 compartments of acrylic, separated by anionic and cationic exchange membranes alternately, with a total effective area of $226.2 \mathrm{~cm}^{2}$, as shown in Figure 1; this unit was constructed in-house. The electrodialysis unit is composed of 4 pairs of cells, with 4 cationic exchange membranes (CR 67 HMR-412, Ionics) and 4 anionic exchange membranes (AR 204 SZRA-412, Ionics), placed alternately and $7 \mathrm{~mm}$ apart from each other.

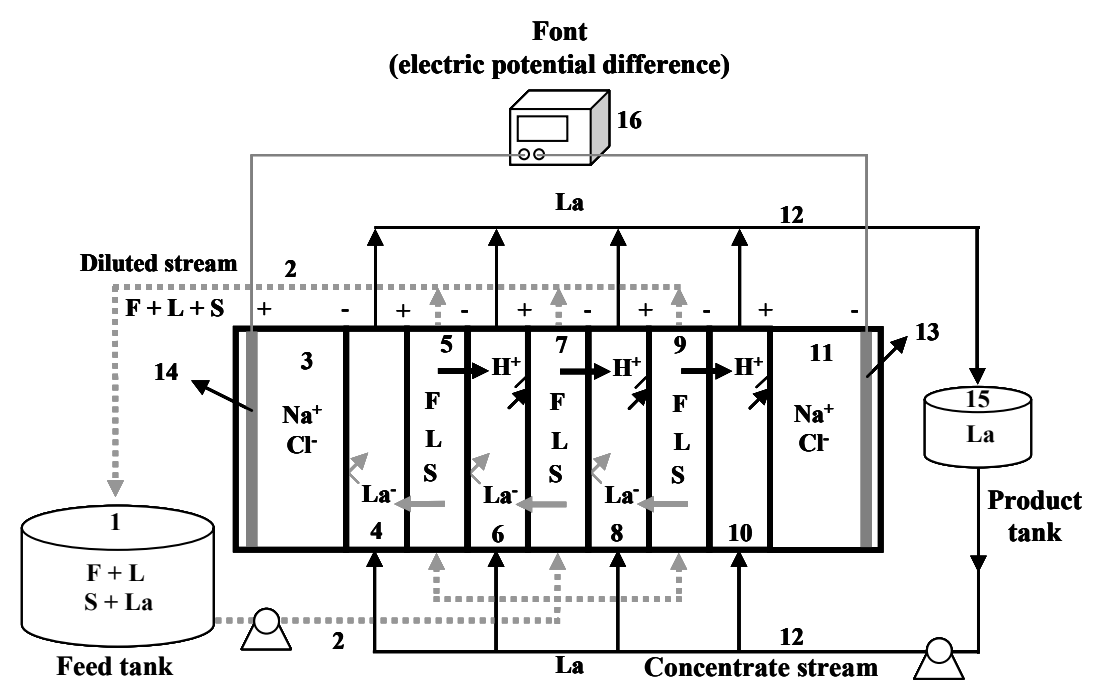

Figure 1: Schematic representation of the electrodialysis unit used in the experiments. The feed (1) was pumped to the compartments 5, 7 and 9, where the non-ionic compounds remained in the dilute stream (2), while lactobionic acid was removed from the compartments $4,6,8$ and 10 , coming out in the concentrated stream (12) for the product tank (15). A continuous current power supply (16) applied the voltage to the carbon electrodes (13 and 14), immersed in the compartments of the electrolytic solution ( 3 and 11). 
According to Figure 1, the feed (1) containing the synthetic solution of fructose, lactose, sorbitol and lactobionic acid (total volume of $150 \mathrm{ml}$ ) was pumped into channels 5, 7 and 9. Because fructose, lactose and sorbitol have no electric charge, they are not attracted by the electrodes, coming out in the dilute stream (2), while the lactobionic ion and the hydrogen ion permeate through the anion exchange membrane and through the cation exchange membrane, respectively, towards compartments $4,6,8$ and 10 , coming out in the concentrated stream (12) and being collected in the tank (15). This separation occurs due to the electrical potential difference applied to the electrodialysis unit by carbon electrodes (13 and 14) using a continuous current power supply (16) from Instrutherm, model FA-3050.

To evaluate the removal of lactobionic acid, a factorial design was employed having as independent variables the potential difference (or voltage), the $\mathrm{NaCl}$ concentration in the electrode compartment and in the concentrated stream. Table 1 shows the levels of the variables used. The voltage ranged from $20 \mathrm{~V}$ to $60 \mathrm{~V}$. The use of voltages lower than $20 \mathrm{~V}$ is not efficient to remove the acid in this system. The limits of the others variables were chosen based on results obtained in preliminary tests.

A factorial design type $2^{3}$ with 3 central points and 6 axial points was chosen, showed in Table 2, and the dependent variable was the specific removal rate of the lactobionic acid $\left(\mathrm{g} \cdot \mathrm{min}^{-1} \cdot \mathrm{m}^{-2}\right)$. Equations (1) to (3) represent the normalized variables, $V^{\text {norm }}$ (voltage), $C_{\mathrm{NaCl}_{-} \text {el }}^{\text {nom }}(\mathrm{NaCl}$ concentration in the electrodes compartment), $C_{\mathrm{NaCl}}^{\text {norm }}(\mathrm{NaCl}$ concentration in the concentrated stream).

$$
V^{\text {norm }}=\frac{\text { Voltage }-40}{11.91}
$$

$$
\begin{gathered}
C_{\mathrm{NaCl} \_ \text {el }}^{\text {norm }}=\frac{C_{\mathrm{NaCl}_{e} \mathrm{el}}-100}{45} \\
C_{\mathrm{NaCl}}^{\text {norm }}=\frac{C_{\mathrm{NaCl}}-1.512}{0.893}
\end{gathered}
$$

All experiments were carried out at $30^{\circ} \mathrm{C}$ and at a flow rate of $201 . \mathrm{h}^{-1}$ using $150 \mathrm{ml}$ of synthetic solutions of lactose $\left(40 \mathrm{~g} \mathrm{~L}^{-1}\right)$, fructose $\left(20 \mathrm{~g} \mathrm{~L}^{-1}\right)$, sorbitol $\left(5 \mathrm{~g} \mathrm{~L}^{-1}\right)$ and lactobionic acid $\left(10 \mathrm{~g} \mathrm{~L}^{-1}\right)$ (Sigma Aldrich, 99\%, all the reagents). The lactobionic acid concentration was monitored indirectly by the feed conductivity (Quimis conductivimeter).

\section{RESULTS AND DISCUSSION}

Figures 2 to 5 show the removal curves of lactobionic acid as a function of the time for all experiments performed. Table 2 shows the values of the specific removal rate of lactobionic acid, calculated from the derivative of the curves at $90 \%$ removal. The observed removal rates varied from 0.58 to 1.48 $\mathrm{g}_{\text {acid }} \cdot \mathrm{min}^{-1} \cdot \mathrm{m}^{-2}$, and in all experiments it was possible to remove more than $95 \%$ of lactobionic acid in less than 2 hours. Figures 2 and 3 show experiments 1-4 and 5-8, respectively. In each set of experiments, the $\mathrm{NaCl}$ concentration in the concentrate stream was the same. The voltage and the $\mathrm{NaCl}$ concentration in the electrode compartment were changed. In both figures it can be observed that, as the voltage increases, the removal rate increases as well, indicating that the $\mathrm{NaCl}$ concentration in the electrode compartment does not exert a significant influence on the removal of lactobionic acid. Figure 4 shows the removal curves for the replicates at the central point, experiments 9-11,

\begin{tabular}{|c|c|c|c|c|c|}
\hline \multirow{2}{*}{ Variable } & \multicolumn{5}{|c|}{ Levels } \\
\hline & -1.68 & -1 & 0 & +1 & +1.68 \\
\hline $\begin{array}{l}\text { Voltage } \\
\text { (V) }\end{array}$ & 20 & 28.09 & 40 & 51.9 & 60 \\
\hline $\begin{array}{l}\mathrm{NaCl} \text { concentration in the } \\
\text { electrode compartment }\left(\mathrm{g} \mathrm{L}^{-1}\right)\end{array}$ & 24.4 & 55 & 100 & 145 & 175.6 \\
\hline $\begin{array}{l}\mathrm{NaCl} \text { concentration in the concentrated } \\
\text { stream }\left(\mathrm{g} \mathrm{L}^{-1}\right)\end{array}$ & 0.0 & 0.619 & 1.512 & 2.404 & 3.0 \\
\hline
\end{tabular}
pointing out the good reproducibility of the data.

Table 1: Levels of the variables used in the experimental design in the electrodialysis unit. 
Table 2: Design matrix for the experiments performed in the electrodialysis unit.

\begin{tabular}{|c|c|c|c|c|c|c|c|}
\hline Exp. & $V^{n o r m}$ & $C_{\text {NaCl_el }}^{\text {norm }}$ & $C_{\mathrm{NaCl}}^{\text {norm }}$ & $\begin{array}{c}\text { Voltage } \\
\text { (V) }\end{array}$ & $\begin{array}{l}\mathrm{NaCl} \text { in the } \\
\text { electrodes } \\
\left(\mathrm{g} \mathrm{L}^{-1}\right)\end{array}$ & $\begin{array}{l}\mathrm{NaCl} \text { in the } \\
\text { concentrate } \\
\left(\mathrm{g} \mathrm{L}^{-1}\right)\end{array}$ & $\begin{array}{c}\text { Specific } \\
\text { removal rate } \\
\left(\mathrm{g} . \mathrm{min}^{-1} . \mathrm{m}^{-2}\right)\end{array}$ \\
\hline 1 & +1 & -1 & +1 & 51.9 & 55 & 2.404 & 1.48 \\
\hline 2 & +1 & +1 & +1 & 51.9 & 145 & 2.404 & 1.33 \\
\hline 3 & -1 & -1 & +1 & 28.09 & 55 & 2.404 & 0.84 \\
\hline 4 & -1 & +1 & +1 & 28.09 & 145 & 2.404 & 0.80 \\
\hline 5 & +1 & -1 & -1 & 51.9 & 55 & 0.619 & 1.13 \\
\hline 6 & +1 & +1 & -1 & 51.9 & 145 & 0.619 & 0.92 \\
\hline 7 & -1 & -1 & -1 & 28.09 & 55 & 0.619 & 0.75 \\
\hline 8 & -1 & +1 & -1 & 28.09 & 145 & 0.619 & 0.76 \\
\hline 9 & 0 & 0 & 0 & 40 & 100 & 1.512 & 1.16 \\
\hline 10 & 0 & 0 & 0 & 40 & 100 & 1.512 & 1.01 \\
\hline 11 & 0 & 0 & 0 & 40 & 100 & 1.512 & 1.03 \\
\hline 12 & -1.68 & 0 & 0 & 20 & 100 & 1.512 & 0.58 \\
\hline 13 & +1.68 & 0 & 0 & 60 & 100 & 1.512 & 1.31 \\
\hline 14 & 0 & -1.68 & 0 & 40 & 24.4 & 1.512 & 1.04 \\
\hline 15 & 0 & +1.68 & 0 & 40 & 175.6 & 1.512 & 1.01 \\
\hline 16 & 0 & 0 & -1.68 & 40 & 100 & 0.0 & 0.67 \\
\hline 17 & 0 & 0 & +1.68 & 40 & 100 & 3.0 & 0.88 \\
\hline
\end{tabular}

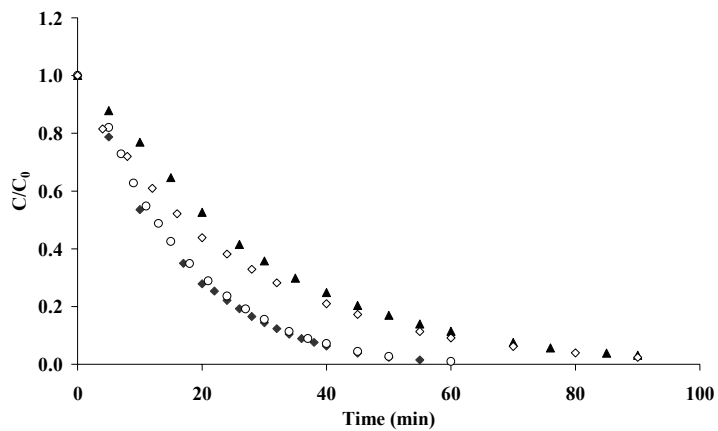

Figure 2: Removal curves of lactobionic acid for experiments 1 to 4 , shown in Table 2 (Exp. 1 $51.9 \mathrm{~V}, 55 \mathrm{~g} \mathrm{~L}^{-1}, 2.404 \mathrm{~g} \mathrm{~L}^{-1}(\bullet)$; Exp. $2-51.9 \mathrm{~V}$, $145 \mathrm{~g} \mathrm{~L}^{-1}, 2.404 \mathrm{~g} \mathrm{~L}^{-1}(\mathrm{O})$; Exp. $3-20.09 \mathrm{~V}, 55 \mathrm{~g} \mathrm{~L}^{-1}$, $2.404 \mathrm{~g} \mathrm{~L}^{-1}(\Delta)$; Exp. $4-28.09 \mathrm{~V}, 145 \mathrm{~g} \mathrm{~L}^{-1}$, $\left.2.404 \mathrm{~g} \mathrm{~L}^{-1}(\diamond)\right)$, where $\mathrm{C}$ is the actual concentration and $\mathrm{C}_{0}$ the initial concentration.

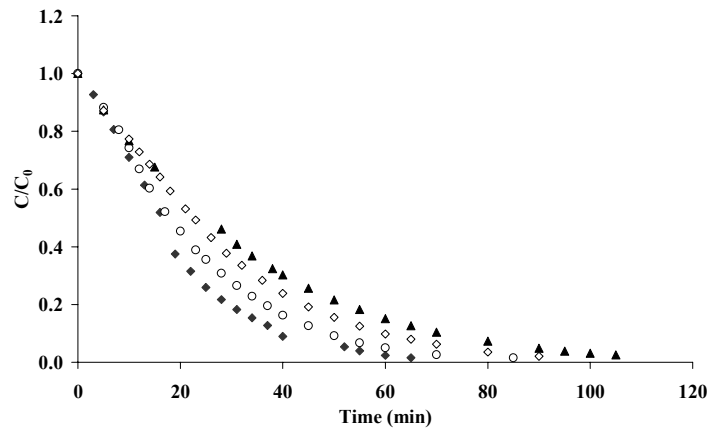

Figure 3: Removal curves of lactobionic acid for experiments 5 to 8, shown in Table 2 (Exp. 5 $51.9 \mathrm{~V}, 55 \mathrm{~g} \mathrm{~L}^{-1}, 0.619 \mathrm{~g} \mathrm{~L}^{-1}(\bullet)$; Exp. $6-51.9 \mathrm{~V}$, $145 \mathrm{~g} \mathrm{~L}^{-1}, 0.619 \mathrm{~g} \mathrm{~L}^{-1}(\mathrm{O})$; Exp. $7-20.09 \mathrm{~V}, 55 \mathrm{~g} \mathrm{~L}^{-1}$, $0.619 \mathrm{~g} \mathrm{~L}^{-1}(\boldsymbol{\Lambda})$; Exp. $8-28.09 \mathrm{~V}, 145 \mathrm{~g} \mathrm{~L}^{-1}, 0.619$ $\left.\mathrm{g} \mathrm{L}^{-1}(\diamond)\right)$, where $\mathrm{C}$ is the actual concentration and $\mathrm{C}_{0}$ the initial concentration.

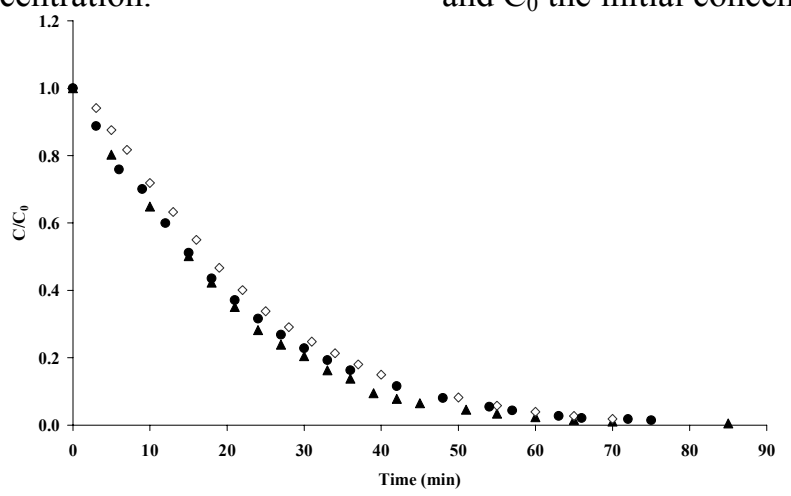

Figure 4: Removal curves of lactobionic acid for experiments 9 to 11 (central points), shown in Table 2 (Exp. 9 - $40 \mathrm{~V}, 100 \mathrm{~g} \mathrm{~L}^{-1}, 1.512 \mathrm{~g} \mathrm{~L}^{-1}$ (ム); Exp. 10 $-40 \mathrm{~V}, 100 \mathrm{~g} \mathrm{~L}^{-1}, 1.512 \mathrm{~g} \mathrm{~L}^{-1}(\diamond)$; Exp. $11-40 \mathrm{~V}$, $\left.100 \mathrm{~g} \mathrm{~L}^{-1}, 1.512 \mathrm{~g} \mathrm{~L}^{-1}(\bullet)\right)$, where $\mathrm{C}$ is the actual concentration and $\mathrm{C}_{0}$ the initial concentration. 
Figure 5 is related to the removal curves of the axial points of the experimental design. It is possible to observe the great influence of the voltage on acid removal as shown in experiments 12 and 13 . With the increase of the voltage from $20 \mathrm{~V}$ to $60 \mathrm{~V}$, the time to remove about $95 \%$ of the lactobionic acid drops from $100 \mathrm{~min}$ to $50 \mathrm{~min}$ approximately. No difference in the specific removal rate of lactobionic acid was observed for changes in the $\mathrm{NaCl}$ concentration in the electrode compartment, which can attributed to the range of $\mathrm{NaCl}$ concentration used. Possibly, the use of values below $25 \mathrm{~g} \mathrm{~L}^{-1}$ could produce some noticeable difference. On the other hand, the $\mathrm{NaCl}$ concentration in the concentrated stream exerts great influence on the removal rate, because the presence of this salt in this stream increases the conductivity and so decreases the resistance to the transport.

Based on the results of the experimental design and using Equation (4), it is possible to analyze the effect of each variable on the removal rate of lactobionic acid, as well as to verify the significance of these effects. According to the theory of factorial design, this equation means that the effects can be represented by a sum of linear contributions. Model parameters and parameter variances can be obtained with the aid of maximum likelihood estimation procedures, as described in the literature (Schwaab and Pinto, 2007).

$$
\begin{aligned}
& \text { Rate }=a_{0}+a_{1} \cdot V^{\text {norm }}+a_{2} \cdot C_{\text {NaCl_el }}^{\text {norm }}+a_{3} \cdot C_{\text {NaCl }}^{\text {norm }} \\
& +a_{4} \cdot V^{n o r m} \cdot C_{N a C l}^{\text {nol } e l}+a_{4} \cdot V^{\text {norm }} \cdot C_{\mathrm{NaCl}_{-} \mathrm{el}}^{\text {norm }} \\
& +a_{5} \cdot V^{\text {norm }} \cdot C_{\mathrm{NaCl}}^{\text {norm }}+a_{6} \cdot C_{\mathrm{NaCl} \_ \text {el }}^{\text {norm }} \cdot C_{\mathrm{NaCl}}^{\text {norm }} \\
& +a_{7} \cdot V^{\text {norm } 2}+a_{8} \cdot\left(C_{\text {NaCl_el }_{\text {el }}}^{\text {norm }}\right)^{2}+a_{9} \cdot\left(C_{\text {NaCl }}^{\text {norm }}\right)^{2}
\end{aligned}
$$

The confidence regions of the parameter estimates can be written in the form:

$$
\theta_{i}^{\text {est }}-\varepsilon_{\theta i}<\theta_{i}^{\text {true }}<\theta_{i}^{\text {est }}+\varepsilon_{\theta i}
$$

where $\theta_{i}^{\text {est }}$ represents the estimated parameter value; $\theta_{i}^{\text {true }}$ represents the "true" (and unknown) parameter value and $\varepsilon_{\theta i}$ represents the parameter uncertainty, obtained with the help of the standard $t$-distribution, in the form:

$\varepsilon_{\theta i}=t \cdot \sigma_{\theta i}$

with the level specified by the user. $\sigma_{\theta i}$ is the standard deviation of the parameter estimate. Thus, for a parameter to be significant, $\varepsilon_{\theta i}$ should be smaller than $\theta_{i}^{\text {est }}$ (Schwaab and Pinto, 2007). Taking this into account, Equation (7) was obtained after a parameter estimation procedure, performed with the software Statistica 6.0 (Statsoft, 2001).

$$
\begin{aligned}
\text { Rate } & =(1.045 \pm 0.028)+(0.215 \pm 0.023) \cdot V^{\text {norm }} \\
& +(0.091 \pm 0.023) \cdot C_{\text {NaCl }}^{\text {norm }} \\
& +(0.078 \pm 0.031) \cdot V^{n o r m} \cdot C_{N a C l}^{\text {norm }} \\
& -(0.078 \pm 0.024) \cdot\left(C_{\mathrm{NaCl}}^{\text {norm }}\right)^{2}
\end{aligned}
$$

Equation (7) shows that the significant parameters with $95 \%$ confidence were the voltage and the $\mathrm{NaCl}$ concentration in the concentrated stream, while the $\mathrm{NaCl}$ concentration in the electrodes compartment did not exert an influence on the specific removal rate of lactobionic acid, within the experimental range used.

Table 3 shows the statistical analysis of the model performance, where:

$\sigma_{\text {experimental }}^{2}=\frac{\sum_{i=1}^{N E}\left(y_{i}^{\text {exp. }}-\bar{y}^{\text {exp. }}\right)^{2}}{N E-1}$

$\sigma_{\text {model }}^{2}=\frac{\sum_{i=1}^{N E}\left(y_{i}^{\text {calc. }}-y_{i}^{\text {exp. }}\right)^{2}}{N E-N P}$

$F_{\text {calculated }}=\frac{\sigma_{\text {model }}^{2}}{\sigma_{\text {experimental }}^{2}}$ or $F_{\text {calculated }}=\frac{\sigma_{\text {experimental }}^{2}}{\sigma_{\text {model }}^{2}}$

$R=\frac{\sum_{i=1}^{N E}\left(y_{i}^{\text {exp. }}-\bar{y}^{\text {exp. }}\right) \cdot\left(y_{i}^{\text {calc. }}-\bar{y}^{\text {calc. }}\right)}{\sqrt{\left[\sum_{i=1}^{N E}\left(y_{i}^{\text {exp. }}-\bar{y}^{\text {exp. }}\right)^{2}\right] \cdot\left[\sum_{i=1}^{N E}\left(y_{i}^{\text {calc. }}-\bar{y}^{\text {calc. }}\right)^{2}\right]}}$

In these equations, $y_{i}^{\text {calc. }}$ and $y_{i}^{\text {exp. }}$ are the predicted and experimental values, respectively; $\bar{y}_{i}^{\text {calc. }}$ and $\bar{y}_{i}^{\text {exp. }}$ are the predicted and experimental average values, respectively; $N E$ and $N P$ are the number of experiments and the number of model parameters, respectively; $\sigma_{\text {experimental }}^{2}$ and $\sigma_{\text {model }}^{2}$ are the experimental and model variances, respectively; $\mathrm{R}$ is the correlation coefficient; $\mathrm{F}_{\text {calculated }}$ is the value of the calculated $\mathrm{F}$.

According to Table 3, the F Test employed between the model and the experimental variances, 
resulting in $\mathrm{F}_{\text {calculated }}$ is within the tabulated interval, meaning that the prediction errors of the model are similar to the experimental errors, as can be observed in Figure 6. It is important to note that an assumption of the factorial design is that the error is constant for all the experimental range. This figure shows that the predicted values are within the experimental errors, represented by the average value of the central point, with its confidence interval, calculated by the $t$ Test with $95 \%$ confidence.

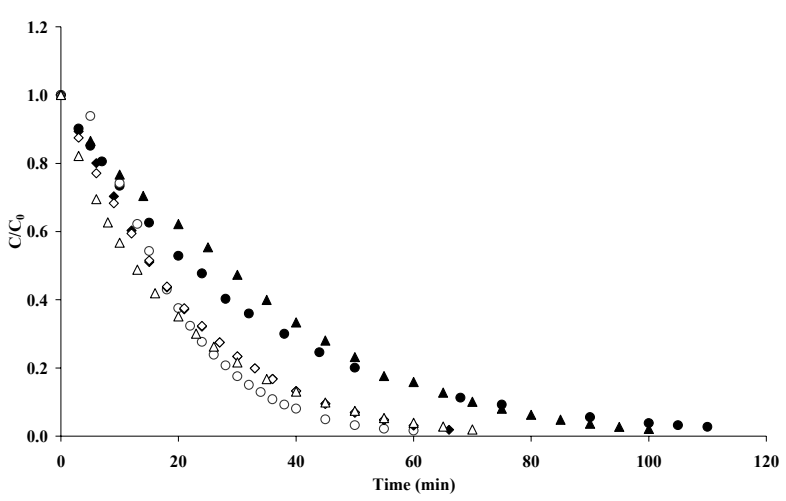

Figure 5: Removal curves of lactobionic acid for experiments 12 to 17 (axial points), shown in Table 2 (Exp. $12-20 \mathrm{~V}, 100 \mathrm{~g} \mathrm{~L}^{-1}, 1.512 \mathrm{~g} \mathrm{~L}^{-1}$ (•); Exp. $13-$ $60 \mathrm{~V}, 100 \mathrm{~g} \mathrm{~L}^{-1}, 1.512 \mathrm{~g} \mathrm{~L}^{-1}(\mathrm{O})$; Exp. $14-40 \mathrm{~V}, 24.4$ $\mathrm{g} \mathrm{L}^{-1}, 1.512 \mathrm{~g} \mathrm{~L}^{-1}(\diamond)$; Exp. $15-40 \mathrm{~V}, 175.60 \mathrm{~g} \mathrm{~L}^{-1}$, $1.512 \mathrm{~g} \mathrm{~L}^{-1}(\diamond)$; Exp. $16-40 \mathrm{~V}, 100 \mathrm{~g} \mathrm{~L}^{-1}, 0.0 \mathrm{~g} \mathrm{~L}^{-1}$ (৯); Exp. $\left.17-40 \mathrm{~V}, 100 \mathrm{~g} \mathrm{~L}^{-1}, 3.0 \mathrm{~g} \mathrm{~L}^{-1}(\triangle)\right)$, where $\mathrm{C}$ is the actual concentration and $\mathrm{C}_{0}$ the initial concentration.

Table 3: F Test between the central points and of model variances (Equation (7)).

\begin{tabular}{|c|c|c|c|c|c|}
\hline \multicolumn{2}{|c|}{ Variance } & \multicolumn{2}{|c|}{$\mathbf{F}_{\text {tabulated }}$} & \multirow{2}{*}{ Correlation coefficient } \\
\cline { 1 - 1 } $\begin{array}{c}\text { Central point } \\
\left(\sigma_{\text {model }}^{2}\right)\end{array}$ & $\begin{array}{c}\text { Model } \\
\left(\sigma_{\text {experimental }}^{2}\right)\end{array}$ & & Inferior & Superior & \\
\hline $6.633 \cdot 10^{-3}$ & $7.694 \cdot 10^{-3}$ & 0.862 & 0.025 & 5.095 & 0.951 \\
\hline
\end{tabular}

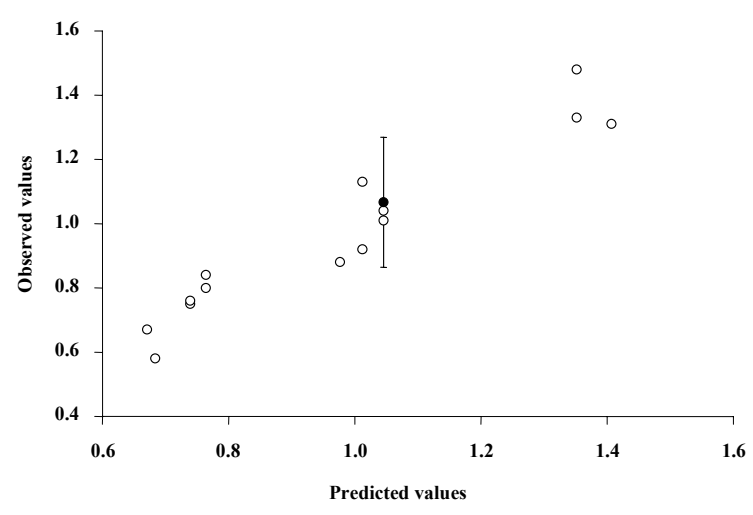

Figure 6: Predicted and observed values for the empirical model represented by Equation (7) $(\bullet-$ central point and its confidence interval with $95 \%$ confidence; $\bigcirc$ - predicted and experimental values). 
Equation (7) also shows that the voltage is the most influential variable, being a linear and positive parameter. In other words, as the voltage increases so does the removal rate. Besides, there is a combination effect between the voltage and the salt concentration in the concentrate stream, indicating the existence of non-linearity in the investigated system. According to Equation (7), the effect of the $\mathrm{NaCl}$ concentration in the concentrated stream goes through a maximum. With support of the software Mathcad, an optimization routine (based on the LevenbergMarquard algorithm) was used to calculate the values of the variables that maximize the specific removal rate in the studied range. Thus, the condition of $60 \mathrm{~V}$ and $3.0 \mathrm{~g} \mathrm{~L}^{-1}$ for the $\mathrm{NaCl}$ concentration in the concentrated stream is the best condition found, as it is evident from Figure 7.

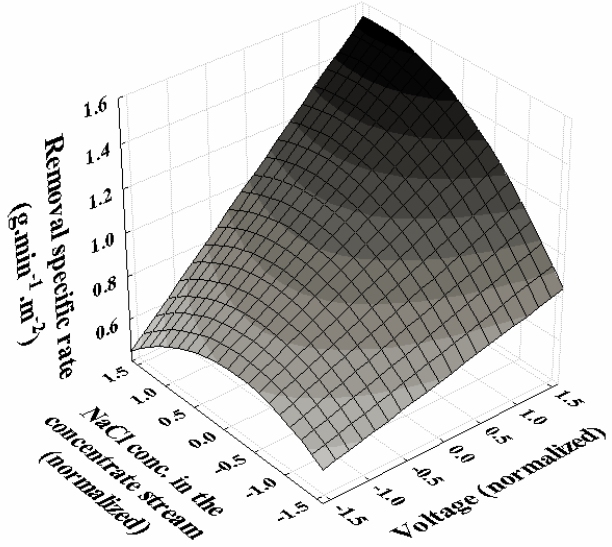

Figure 7: Behavior of the specific removal rate as a function of the voltage and $\mathrm{NaCl}$ concentration in the concentrated stream, based on Equation (7).

Figure 8 shows the apparent resistance of the electrodialysis unit calculated for experiments 12 and 13, in order to evaluate the voltage effect. Experiments 16 and 17 show the influence of the salt concentration in the concentrated stream. The apparent resistance of the electrodialysis unit was calculated based on Equation (12), Ohm's law, as follows:

$$
\Omega=\frac{V}{i}
$$

where $V$ and $i$ are the applied tension and the electrical current of the system, respectively.

It is possible to verify in Figure 8 that, for experiments 12 and 13 , as the voltage increased from $20 \mathrm{~V}$ to $60 \mathrm{~V}$, the electrical resistance of the system decreased because the electrical current increased.
The effect of the salt concentration in the concentrated stream is evident in Figure 8, because at the very beginning of the experiment (time $=0$ ), the apparent resistance of the unit without addition of salt is about $500 \mathrm{Ohms}$, while with $3 \mathrm{~g} \mathrm{~L}^{-1}$ salt solution it is $60 \mathrm{Ohms}$; since the ions in the solution increased the conductivity in the channels between the membranes, thus the transport resistance decreased.

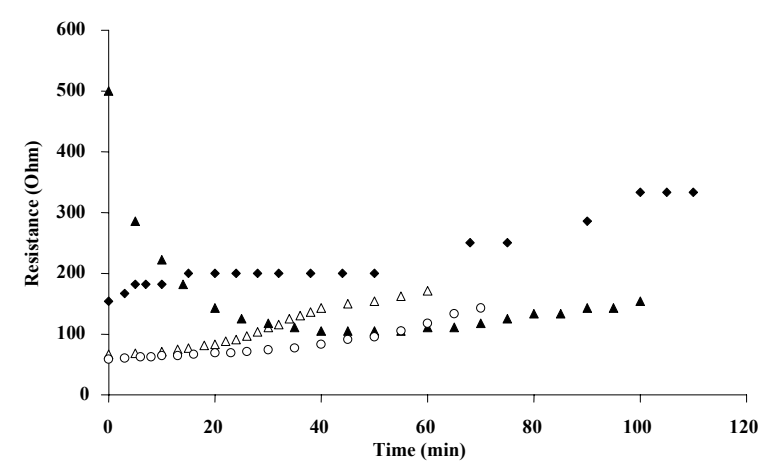

Figure 8: Apparent electrical resistance of the electrodialysis system for experiments $12,13,16$ and 17 of Table 2 (Exp. $12-20 \mathrm{~V}, 100 \mathrm{~g} \mathrm{~L}^{-1}, 1.512 \mathrm{~g} \mathrm{~L}^{-1}$ (•); Exp. $13-60 \mathrm{~V}, 100 \mathrm{~g} \mathrm{~L}^{-1}, 1.512 \mathrm{~g} \mathrm{~L}^{-1}(\triangle)$; Exp. $16-40 \mathrm{~V}, 100 \mathrm{~g} \mathrm{~L}^{-1}, 0.0 \mathrm{~g} \mathrm{~L}^{-1}(\mathbf{\Lambda})$; Exp. $17-40 \mathrm{~V}$, $\left.100 \mathrm{~g} \mathrm{~L}^{-1}, 3.0 \mathrm{~g} \mathrm{~L}^{-1}(\mathrm{O})\right)$.

For all experiments of the factorial design, a removal of lactobionic acid superior to $95 \%$ was obtained in less than $100 \mathrm{~min}$. In a similar work (Peretti et al., 2009), a removal of $38.7 \%$ of lactobionic acid from synthetic mixtures was obtained in about 250 $\min$ and at $15 \mathrm{~V}$.

The results presented in this work show that this membrane separation process can be successfully integrated into the step of production of sorbitol and lactobionic acid by permeabilized cells of Zymomonas mobilis from lactose and fructose, with a possible positive effect of avoiding the enzyme inhibition (Furlinger et al., 1998; Ferraz et al., 2001). For a lactobionic acid production rate of $1 \mathrm{~g}_{\text {acid }} \cdot \mathrm{g}_{\text {cell }}{ }^{-1} \cdot \mathrm{h}^{-1}$ (the highest obtained in our previous studies), using $1 \mathrm{~g}$ of cells, a membrane area inferior to $100 \mathrm{~cm}^{2}$ would be needed.

\section{CONCLUSIONS}

The results of the proposed experimental design showed that the variables with the greatest influence on the lactobionic acid removal rate by electrodialysis are the $\mathrm{NaCl}$ concentration in the concentrated stream and the voltage. The increase in the value of these variables results in an increase of the driving 
force, thus facilitating the removal. The best conditions for the separation of the acid within the studied range were $60 \mathrm{~V}, 3 \mathrm{~g} \mathrm{~L}^{-1}$ of $\mathrm{NaCl}$ in the concentrated stream and $25 \mathrm{~g} \mathrm{~L}^{-1}$ of $\mathrm{NaCl}$ in the electrode compartment.

In all experiments it was possible to remove more than $95 \%$ of lactobionic acid in less than 2 hours. The increase of the number of cell pairs of the electrodialysis stack, and thus in the membrane area, is easily accomplished due to its modular design, allowing the prompt scale-up of this process. This work opens new perspectives for the industrial production of sorbitol and lactobionic acid, which is currently still based on conventional processes.

\section{NOMENCLATURE}

\section{Latin Letters}

\begin{tabular}{|c|c|c|}
\hline$a_{i}$ & $\begin{array}{l}\text { coefficients of the empirical } \\
\text { model }\end{array}$ & $(-)$ \\
\hline$C_{\mathrm{NaCl}}$ & $\begin{array}{l}\mathrm{NaCl} \text { concentration in the } \\
\text { concentrated stream }\end{array}$ & $\mathrm{g} \mathrm{L}^{-1}$ \\
\hline$C_{\mathrm{NaCl}}^{\text {norm }}$ & $\begin{array}{l}\text { normalized } \mathrm{NaCl} \\
\text { concentration in the } \\
\text { concentrated stream }\end{array}$ & $(-)$ \\
\hline$C_{\mathrm{NaCl}_{-} e l}$ & $\begin{array}{l}\mathrm{NaCl} \text { concentration in the } \\
\text { electrode compartment }\end{array}$ & $\mathrm{g} \mathrm{L}^{-1}$ \\
\hline$C_{\mathrm{NaCl} \text { el }}^{\text {norm }}$ & $\begin{array}{l}\text { normalized } \mathrm{NaCl} \\
\text { concentration in the electrode } \\
\text { compartment }\end{array}$ & $(-)$ \\
\hline$F_{\text {calculated }}$ & value of the calculated $F$ & $(-)$ \\
\hline$i$ & $\begin{array}{l}\text { electrical current of the } \\
\text { system }\end{array}$ & 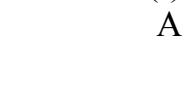 \\
\hline$N E$ & number of experiments & $(-)$ \\
\hline$N P$ & $\begin{array}{l}\text { number of parameter of the } \\
\text { model }\end{array}$ & $(-)$ \\
\hline $\mathrm{R}$ & correlation coefficient & $(-)$ \\
\hline Rate & specific removal rate & $\mathrm{g}_{\text {acid }} \mathrm{g}_{\text {cell }}{ }^{-1} \mathrm{~h}^{-1}$ \\
\hline$t$ & value of the $t$-distribution & $(-)$ \\
\hline$V$ & applied voltage & V \\
\hline$V^{\text {norm }}$ & normalized voltage & $(-)$ \\
\hline $\bar{y}_{i}^{\text {calc. }}$ & $\begin{array}{l}\text { average data predicted by } \\
\text { the model }\end{array}$ & $\mathrm{g}_{\text {acid }} \mathrm{g}_{\text {cell }}{ }^{-1} \mathrm{~h}^{-1}$ \\
\hline$y_{i}^{\text {calc. }}$ & values predicted by the model & $\mathrm{g}_{\text {acid }} \mathrm{g}_{\text {cell }}{ }^{-1} \mathrm{~h}^{-1}$ \\
\hline $\bar{y}^{\exp }$ & average experimental data & $\mathrm{g}_{\text {acid }} \mathrm{g}_{\text {cell }}{ }^{-1} \mathrm{~h}^{-1}$ \\
\hline$y_{i}^{e x p}$ & experimental values & $\mathrm{g}_{\text {acid }} \mathrm{g}_{\text {cell }}{ }^{-1} \mathrm{~h}^{-1}$ \\
\hline
\end{tabular}

\section{Greek Letters}

$\varepsilon_{\theta i} \quad$ parameter uncertainty

$\theta_{i}^{\text {est }} \quad$ estimated parameter value

$$
\begin{array}{ll}
\theta_{i}^{\text {true }} & \begin{array}{l}
\text { "true" (and unknown) } \\
\text { parameter value }
\end{array} \\
\sigma_{\theta i} & \begin{array}{l}
\text { standard deviation of the } \\
\text { parameter estimate } \\
\text { the experimental variances }
\end{array} \\
\sigma_{\text {experimental }}^{2} & \text { the model variances } \\
\sigma_{\text {model }}^{2} & \text { apparent resistance }
\end{array}
$$

ohm

\section{REFERENCES}

Bélafi-Bakó, K., Nemestóthy, N., Gubicza, L., Study on application of membrane techniques in bioconversion of fumaric acid to L-malic acid. Desalination, 162, 301 (2004).

Choi, J-H., Kim, S-H., Moon, S-H., Recovery of lactic acid from sodium lactate by ion substitution using ion-exchange membrane. Separation and Purification Technology, 28, 69 (2002).

Dhariwal, A., Mavrov, V., Schroeder, I., Production of lactobionic acid with process integrated electrochemical enzyme regeneration and optimisation of process variables using response surface methods (RSM). Journal of Molecular Catalysis B: Enzymatic, 42, 64 (2006).

Ferraz, H. C., Alves, T. L. M., Borges, C. P., Coupling of an electrodialysis unit to a hollow fiber bioreactor for separation of gluconic acid from sorbitol produced by Zymomonas mobilis permeabilized cells. Journal of Membrane Science, 191, 43 (2001).

Furlinger, M., Haltrich, D., Kulbe, K. D., Nidetzky, B., A multistep process is responsible for productinduced inactivation of glucose-fructose oxidoreductase from Zymomonas mobilis. European Journal of Biochemistry, 251, 955 (1998).

Jonas, R., Silveira, M. M., Sorbitol can be produced not only chemically but also biotechnologically. Applied Biochemistry and Biotechnology, 118, 321 (2004).

Malvessi, E., Carra, S., Pasquali, F. C., Kern, D. B., Silveira, M. M., Ayub, M. A. Z., Production of organic acids by periplasmic enzymes present in free and immobilized cells of Zymomonas mobilis. Journal of Industrial Microbiology Biotechnology, 40, 1 (2013).

Miyamoto, Y., Ooi, T., Kinoshita, S., Production of lactobionic acid from whey by Pseudomonas sp. LS13-1. Biotechnology Letters, 22, 427 (2000).

Molnár, E., Eszterle, M., Kiss, K., Nemestóthy, N., Fekete, J., Bélafi-Bakó, K., Utilization of electrodialysis for galacturonic acid recovery. Desalination, 241, 81 (2009). 
Molnár, E., Nemestóthy, N., Bélafi-Bakó, K., Utilisation of bipolar electrodialysis for recovery of galacturonic acid. Desalination, 250, 1128-1131 (2010).

Novalic, S., Kongbangrend, T., Kulbe, K. D., Recovery of organic acids with high molecular weight using a combined electrodialytic process. Journal of Membrane Science, 166, 99 (2000).

Paul, L. H. M., Patrick, F. F., Advanced Dairy Chemistry: Lactose, Water, Salts and Minor Constituents. Springer, New York, v. 3 (2009).

Pedruzzi, I., Silva, E. A. B., Rodrigues, A. E., Production of lactobionic acid and sorbitol from lactose/fructose substrate using GFOR/GL enzymes from Zymomonas mobilis cells: A kinetic study. Enzyme and Microbial Technology, 49, 183 (2011).

Peretti, F. A., Silveira, M. M., Zeni, M., Use of electrodialysis technique for the separation of lactobionic acid produced by Zymomonas mobilis. Desalination, 245, 626 (2009).

Schwaab, M., Pinto, J. C., Análise de dados experimentais I - fundamentos de estatística e esti- mação de parâmetros. E-papers, Brazil, v. 1 (2007). (In portuguese).

Severo Júnior, J. B., Pinto, J. C., Ferraz, H. C., Alves, T. L. M., Production of lactobionic acid and sorbitol using the GFOR (glucose-fructose oxidoreductase) enzyme from permeabilized cells of $Z y$ momonas mobilis. Journal of Industrial Microbiology Biotechnology, 38, 1575 (2011).

Splechtna, S., Petzelbauer, I., Bamingerm, U., Haltrich, D., Kulbe, K. D., Nidetzky, B., Production of a lactose-free galacto-oligosaccharide mixture by using selective enzymatic oxidation of lactose into lactobionic acid. Enzyme and Microbial Technology, 29, 434 (2001).

StatSoft, Inc., STATISTICA (Data Analysis Software System), version 6. www.statsoft.com (2001).

Tongwen, X., Weihua, Y., Citric acid production by electrodialysis with bipolar membranes. Chemical Engineering and Processing, 41, 519 (2002)

Zachariou, M., Scopes, R. K., Glucose-fructose oxidoreductase, a new enzyme isolated from Zymomonas mobilis that is responsible for sorbitol production. Journal of Bacteriology, 167, 863 (1986). 